PERM JOURNAL OF PETROLEUM AND MINING ENGINEERING

ВЕСТНИК ПНИПУ. ГЕОЛОГИЯ. НЕФТЕГАЗОВОЕ И ГОРНОЕ ДЕЛО

ISSN 2224-9923

Volume/ ToM 16 №2 2017

http://vestnik.pstu.ru/geo/

УДК 662.692

Article / Статья

(C) PNRPU / ПНИПУ, 2017

\title{
FEATURES OF DISTRIBUTION OF TEMPERATURE ALONG THE LENGTH OF OIL PIPELINE
}

\author{
Abbas G. Rzaev, Sakit R. Rasulov ${ }^{1}$, Farkhad G. Pashaev, Mikhail A. Salii ${ }^{1}$
}

Institute of Control Systems of Azerbaijan National Academy of Sciences (9 B.Vakhabzade st., Baku, AZ1141, Republic of Azerbaijan)

${ }^{1}$ Azerbaijan State Oil and Industrial University (34 Azadlyg av., Baku, AZ1010, Republic of Azerbaijan)

\section{ХАРАКТЕРНЫЕ ОСОБЕННОСТИ РАСПРЕДЕЛЕНИЯ ТЕМПЕРАТУРЫ ПО ДЛИНЕ НЕФТЕПРОВОДА}

\section{А.Г. Рзаев, С.Р. Расулов ${ }^{1}$, Ф.Г. Пашаев, М.А. Салий ${ }^{1}$}

Институт систем управления Национальной академии наук Азербайджана (AZ1141, Азербайджан, г. Баку, ул. Б. Вахабзаде, 9)

${ }^{1}$ Азербайджанский государственный университет нефти и промышленности (AZ1010, Азербайджан, г. Баку, пр. Азадлыг, 34)

Received / Получена: 22.02.2017. Accepted / Принята: 27.04.2017. Published / Опубликована: 30.06.2017

\section{Key words:}

oil emulsion, thermal conductivity, heat transfer, friction, viscosity, heat balance, temperature, density, oil pipeline, flow, environment, water concentration, hydraulic resistance, volume rate, gas.

\begin{abstract}
One of the actual challenges in fluid (oil, water and gas) transportation from wells to oil treatment installation is determination of a law of temperature distribution along the length of a pipeline at low ambient temperature. That temperature leads to increase in viscosity and deposition of wax on inner surface of a pipe. To overcome that challenge it is needed to consider several defining characteristics of formation fluid (FF) flow. Complexity of a solution is caused by two factors. From the one hand, in most cases (especially on a late stage of field development) FF is an oil emulsion (OE) that contains gas bubbles. From the other hand, temperature gradient between fluid flow and the environment has significant value (especially in the winter period of the year). At the same time, the higher content of emulsified water droplets (EWD) in OE and lower flow temperature, the higher FF viscosity, and consequently productivity (efficiency) of oil pumping system is reduced. Performed research and analysis of field experimental data showed that a function of oil viscosity versus temperature has a hyperbolic law; a function of OE viscosity versus concentration of EWD has a parabolic one. A heat balance for a certain section of a pipeline in steady state of fluid motion using a method of separation of variables was established taking into account above mentioned factors, Fourier's empirical laws on heat conductivity and Newton's law on heat transfer. As a result, unlike existing works, an exponential law of distribution of temperature along the length of a pipeline is obtained. A law takes into account nonlinear nature of change in viscosity of $\mathrm{OE}$ from change in temperature of flow and concentration of water in an emulsion.
\end{abstract}

Ключевые слова: нефтяная эмульсия, теплопроводность, теплопередача, трение, вязкость, тепловой баланс, температура, плотность, нефтепровод, поток, окружающая среда, концентрация воды, гидравлическое сопротивление, объемный расход, газ.
Одной из актуальных проблем при перекачке пластового флюида (нефти, воды и газа) от скважин до установки подготовки нефти является определение закона распределения температуры по длине нефтепровода при низкой температуре окружающей среды, приводящей к повышению вязкости и отложению на внутренней поверхности трубы асфальтеносмолопарафинистых веществ. Решение данной проблемы требует учета некоторых определяющих характеристик потока пластового флюида (ПФ). Сложность решения этой задачи заключается в том, что, с одной стороны, в большинстве случаях (особенно на поздней стадии разработки месторождения) ПФ является нефтяной эмульсией, содержащей газовые пузырьки, с другой стороны, градиент температуры между потоком жидкости и окружающей средой имеет существенное значение (особенно в зимний период года). При этом с повышением содержания эмульгированных водяных капель (ЭВК) в нефтяной эмульсии и с понижением температуры потока вязкость Пж повышается, и, следовательно, снижается производительность (эффективность) нефтеперекачивающей системы. Проведенные исследования и анализ промысловых экспериментальных данных показали, что изменение вязкости нефти от значения температуры описывается гиперболическим законом, а вязкость нефтяной эмульсии от концентрации ЭВК - параболическим. С учетом этих факторов и эмпирических законов Фурье о теплопроводности, Ньютона о теплопередаче составлен баланс тепла для определенного участка нефтепровода при установившемся режиме движения жидкости с использованием метода разделения переменных. В результате, в отличие от существующих работ, получен экспоненциальный закон распределения температуры по длине нефтепровода, учитывающий нелинейный характер изменения вязкости нефтяной эмульсии в зависимости от изменения температуры потока и концентрации воды в эмульсии.

\footnotetext{
Abbas G. Rzaev (Author ID in Scopus: 6701722581) - Doctor of Technical Sciences, Professor, Chief Researcher (tel.: +994 503 95 40 08, e-mail: abbas_r@mail.ru). Sakit R. Rasulov (Author ID in Scopus: 56604027000) - Academician of the Russian Academy of Natural Sciences, Honored Engineer of the Azerbaijan Republic, Doctor of Technical Sciences, Professor, Head of the Department of Industrial Safety and Labor Protection (tel.: +994 5021208 35, e-mail: rasulovsakit@gmail.com). The contact person for correspondence. Farkhad G. Pashaev (Author ID in Scopus: 14009169600) - Doctor of Technical Sciences, Senior Researcher (tel.: +994 504912680 , e-mail: rasulovsakit@gmail.com). Mikhail A. Salii - Doctorate student (+994 5033775 69, e-mail: rasulovsakit@gmail.com).

Рзаев Аббас Гейдар оглы - доктор технических наук, профессор, главный научный сотрудник (+994 503 95 40 08, e-mail: abbas r@mail.ru). Расулов Сакит Рауф оглы - академик РАЕН, заслуженный инженер Азербайджанской Республики, доктор технических наук, профессор, заведующий кафедрой промышленной безопасности и охраны труда (+994 5021208 35, e-mail: rasulovsakit@gmail.com). Контактное лицо для переписки. Пашаев Фархад Гейдар оглы - доктор технических наук, ведущий научный сотрудник (+994 50491 26 80, e-mail: rasulovsakit@gmail.com). Салий Михаил Анатольевич - докторант (+994 5033775 69, e-mail: rasulovsakit@gmail.com).
} 


\section{Introduction}

Low environmental temperature that surround a pipeline from oil production wells to an oil treatment unit leads to increase in viscosity, presipitation of wax on inner walls of a pipeline and as a result to friction head loss. Determination of temperature distribution along a pipeline is one of the important challenges in upstream.

In order to determine friction head loss $h_{f r}$ along a pipeline of round section the DarcyWeisbach equation is used [1-3]:

$$
h_{f r}=\lambda \frac{l}{D} \frac{\vartheta^{2}}{2 \rho}=i \cdot l,
$$

where $\lambda$ is for coefficient of hydraulic resistance that depends on the Reynolds number and relative roughness of the inner surface of a pipeline; $l$ and $D$ are for length and diameter of a pipeline, $\mathrm{m} ; \rho$ is for liquid density, $\mathrm{kg} / \mathrm{m}^{3} ; \vartheta$ is for average speed of liquid flow, $\mathrm{m} / \mathrm{s}$.

As a result of friction on elementary section of a pipeline $d z$ some work are lost. That work is represented by the equation

$$
G_{\mathrm{T}}=\frac{G_{O E} \rho_{O E} g i d z}{E},
$$

where $G_{O E}, \rho_{O E}$ are for volumetric rate, $\mathrm{m}^{3} / \mathrm{h}$, and density, $\mathrm{kg} / \mathrm{m}^{3}$, of oil emulsion respectively; $g$ is for gravity, $\mathrm{m}^{2} / \mathrm{s} ; z$ is for distance from oil production wells, $\mathrm{m}$; $E$ is for mechanical equivalent of heat (1 $\mathrm{kcal}=427 \mathrm{kgs} \cdot \mathrm{m}=427 \cdot 9,81 \mathrm{~N} \cdot \mathrm{m})$.

There are formula (2) is used in [1,4] to determine a degree of liquid distribution along the pipeline. However, this formula does not reflect direct effect of oil viscosity on a temperature value.

If we write heat balance for an elementary section of a pipeline $d z$ under steady-state fluid motion and solve a composite differential equation using the method of separation of variables, then we get an exponential function of change of current temperature value versus length of a pipeline, temperature at the beginning of a pipeline and temperature of surrounding environment [1, 4]. However, as it is shown in [1], one of determining factors of fluid flow (oil, water, gas) such as oil viscosity in a pipeline is not considered. The value of this factor is also reinforced by the fact that in real conditions it is not oil, which was the subject of research by the authors of the works [1,3, 5-13], but a much more complex oil emulsion with a gas mixture flows inside a pipeline from oil production wells to an oil treatment unit. At the same time, flow of mixture and gas in comparison with oil flow leads to additional increase in $\lambda$ value and $h_{f r}$ consequently.

In order to take into account viscosity solution of a differential equation was done using a simplified method (linear dependence) of change in viscosity from change in a value of current temperature [3].

\section{Challenge statement}

Based on the analysis of existing works it follows that establishment of a law for distribution of temperature along a pipeline, taking into account nonlinear character of change in viscosity of an oil emulsion from change in temperature of flow of formation fluid (water, oil and gas) and concentration of water in an oil emulsion as well as initial temperature of flow and temperature of the surrounding environment is an urgent task.

\section{Challenge solution}

Our studies and analysis of field experimental data have shown that change in oil viscosity as a function of temperature is described by hyperbolic law

$$
\mu_{\mathrm{O}}=\frac{a_{1}}{b+c t}
$$

and viscosity of an oil emulsion is determined by the following equation:

$$
\begin{gathered}
\mu_{O E}=\mu_{O} \cdot \beta=\mu_{O}\left[1+s w+\alpha w^{2}\right]= \\
=\frac{a_{1} \beta}{b+c t}=\frac{a}{b+c t},
\end{gathered}
$$

where $\mu_{O}, \mu_{O E}$ are for viscosities of oil and oil emulsion respectively, $\mathrm{g} /(\mathrm{cm} \cdot \mathrm{s})$ (Poise) or $1.019 \cdot 10^{-4} \quad(\mathrm{~kg} \cdot \mathrm{s}) / \mathrm{m}^{2} \quad(\mathrm{~Pa}) ; \quad w$ is for the concentration of emulsified water droplets in an oil 
emulsion; $a, b, c, s, \alpha$ are for coefficients determined experimentally; $t$ is for temperature of an oil emulsion, ${ }^{\circ} \mathrm{C}$.

The amount of heat released from friction of an oil emulsion over a corresponding section of a pipe length $d z$ over the time $d \tau$ is determined by the following equation

$$
G_{h}=\frac{128 G_{O E}^{2} \mu_{O E}}{\pi D^{4} E} d z \cdot d \tau
$$

The amount of heat lost by flow of an oil emulsion flowing during time $d \tau$ through the area of interest is expressed by the equation [14-16]

$$
G_{L}=G_{O E} \rho_{O E} C_{O E} \frac{d t}{d z} d z \cdot d \tau
$$

where $\rho_{O E}=w \rho_{w}+(1-w) \rho_{\mathrm{O}}, C_{O E}=w C_{w}+(1-w) C_{O}$, $\rho_{w}, \rho_{O}, \rho_{O E}$ are for the density of water, oil and an oil emulsion respectively, $\mathrm{kg} / \mathrm{m}^{3} ; C_{w}, C_{O}, C_{O E}$ are for specific heat of water, oil and an oil emulsion, $\mathrm{kcal} /\left(\mathrm{kg} \cdot{ }^{\circ} \mathrm{C}\right)$.

Then, using Newton's cooling law [14-16], it is possible to determine amount of heat lost by a pipeline wall in a cooling medium with a temperature $t_{1}$ along $d z$ in time $d \tau$ [16-18]:

$$
\begin{gathered}
G_{H L}=\pi D K_{1}\left(t-t_{1}\right) d z \cdot d \tau, \\
K_{1}=\lambda_{a v} \frac{\left(t_{\text {wall }}-t_{1}\right)}{\left(t_{\text {liq }}-t_{\text {wall }}\right) \delta}, \\
\lambda_{a v}=\frac{\left(\lambda_{1} h_{O}+\lambda_{2} h_{\text {wall }}+\lambda_{3} h_{g r}\right)}{\delta},
\end{gathered}
$$

where $K_{1}$ is for heat transfer coefficient, $\mathrm{kcal} /\left(\mathrm{m}^{2} \cdot{ }^{\circ} \mathrm{C} \cdot \mathrm{h}\right) ; \lambda_{\mathrm{cp}}$ is for average heat conductivity of an adhesive oil layer (or wax), wall of oil pipeline and layer of soil covering the pipeline, $\mathrm{kcal} /\left(\mathrm{m}^{2} \cdot{ }^{\circ} \mathrm{C} \cdot \mathrm{h}\right) ; t_{\text {wall }}, t_{1}$ and $t_{\text {liq }}$ are for temperature of a wall of pipeline, the environment and liquid in the pipe respectively, ${ }^{\circ} \mathrm{C} ; \delta$ is for the total thickness of a near-wall oil layer, a wall of pipe and ground, $\delta=h_{O}+h_{\text {wall }}+h_{g r} ; h_{O}, h_{\text {wall }}$ and $h_{g r}$ are for thickness of an oil layer, walls of an oil pipeline and soil, $\mathrm{m}$; $\lambda_{1}, \lambda_{2}, \lambda_{3}$ are for corresponding thermal conductivities of mentioned layers.
In order to determine average flow speed of a liquid in a round circle tube the parabolic Stokes law is used [19-20], i.e.

$$
\vartheta=\frac{1}{4 \mu_{O E}}\left(\frac{D^{2}}{4}-r^{2}\right)-\left(-\frac{\partial p}{\partial z}\right),
$$

where $r$ is for a parameter expressing change in thickness of a liquid from the center of the flow to the wall.

In this case, fluid flow rate $G$ is determined as follows:

$$
G=\int_{0}^{D / 2} 2 \pi r d r \cdot \vartheta=-\left(\frac{\partial p}{\partial z}\right) \frac{\pi D^{4}}{128 \mu_{O E}} .
$$

Taking into account (9) and (10), we obtain

$$
\begin{gathered}
G_{\mathrm{H}}=\int_{0}^{\frac{D}{2}} 2 \pi r \frac{\mu_{O E}}{E}\left(\frac{\partial \vartheta}{\partial r}\right)^{2} d z d \tau d r= \\
=\frac{\pi D^{4}}{128 \mu_{O E} E}\left(\frac{128^{2} G_{O E}^{2} \mu_{O E}^{2}}{\left(\pi D^{4}\right)^{2}}\right) d z \cdot d \tau= \\
=\frac{128 G_{O E}^{2} \mu_{O E}}{\pi D^{4} E} \cdot d z \cdot d \tau,
\end{gathered}
$$

where $p, \vartheta$ are pressure, Pa, and average speed of an oil emulsion flow, $\mathrm{m} / \mathrm{h} ; \tau$ is for time, $\mathrm{h}$.

On the basis of the above mentiond, we compose heat balance for an elementary section of a pipe $d z$ under steady-state flow conditions of an oil emulsion:

$$
\begin{gathered}
\Delta G=G_{H}-G_{L}-G_{H L}=\frac{128 G_{O E}^{2} \mu_{O E}}{\pi D^{4} E}- \\
-G_{O E} \rho_{O E} C_{O E} \frac{d t}{d z}-\pi D K_{1}\left(t-t_{1}\right)=0
\end{gathered}
$$

To determine distribution (change) of temperature of an oil emulsion flow along the length of a pipeline from oil production wells to an oil treatment unit, integrating the differential equation (11), taking into account formula (1), we obtain

$$
\begin{gathered}
J_{3} \int \frac{b+c t}{c J_{1} t^{2}+J_{1}\left(b-c t_{1}\right) t-\left(b J_{1} t_{1}+J_{2} a\right)} d t= \\
=-z+c_{1},
\end{gathered}
$$


where $J_{1}=\pi D K_{1}, J_{2}=\frac{128 G_{O E}^{2}}{\pi D^{4} E} ; J_{3}=G_{O E} \cdot \rho_{O E} \cdot C_{O E}$; $t, t_{1}$ are for current temperature and temperature surrounding oil pipeline, ${ }^{\circ} \mathrm{C} ; c_{1}$ is for integration constant; $z$ is for distanve from oil production wells, $\mathrm{m}$.

Taking the notation $c J_{1}=r ; \quad J_{1}\left(b-c t_{1}\right)=d$; $b J_{1} T_{1}+J_{2} a=e$, we transform the integral (12) into the following type:

$$
J_{3} \int \frac{b+c t}{r t^{2}+d t-e} d t=-z+c_{1} .
$$

After some transformations the integral (13) looks as follows

$$
\frac{J_{3}}{r} \int \frac{b+c t}{(t+n)(t+m)} d t=-z+c_{1} \text {. }
$$

Solution for the integral equation (14) is

$$
K_{1} \cdot \ln \left[c_{1}(t+n)^{p} \cdot(t+m)^{q}\right]=-z+c_{1}
$$

Values of $c_{1}$ are estimated for initial conditions $z=0, t=t_{0}$

$$
c_{1}=K_{1} \ln \left[c_{2}\left(t_{0}+n\right)^{p} \cdot\left(t_{0}+m\right)^{q}\right] \text {, }
$$

where $n, m, p, q$ are for variable coefficients that are determined depending on technological parameters, i.e.

$$
\begin{aligned}
& n=\frac{1}{2 r}\left[d-\left(d^{2}+4 r e\right)^{1 / 2}\right], \\
& m=\frac{1}{2 r}\left[d+\left(d^{2}+4 r e\right)^{1 / 2}\right], \\
& p=c_{1} n-b, \\
& q=b-c_{1} m, \\
& K_{1}=\frac{1}{r(n-m)},
\end{aligned}
$$

where $d=J_{1}\left(b-c t_{1}\right), e=b J_{1} t_{1}+J_{2} a_{2}, r=c J_{1}$.

As a result, we obtain desired equation for dependence of change in temperature of an oil emulsion flow on initial temperature $\left(t_{0}\right)$ and distance along an oil pipeline from oil production wells to the current point $(z)$ :

$$
\begin{gathered}
(t+n)^{p} \cdot(t+m)^{q}= \\
=\left(t_{0}+n\right)^{p} \cdot\left(t_{0}+m\right)^{q} \exp \left(-\frac{z}{J_{3} K_{1}}\right) .
\end{gathered}
$$

Thus, calculated values of temperature distribution of an oil emulsion flow along an oil pipeline from oil production wells to an oil treatment unit were determined depending on distance (table).

Calculated values of temperature distribution along an pipeline

\begin{tabular}{|c|c|c|c|c|c|c|c|c|c|}
\hline \multirow{3}{*}{$w$} & \multicolumn{7}{|c|}{$Z, \mathrm{~m}$} \\
\cline { 2 - 9 } & 0 & 2000 & 4000 & 6000 & 8000 & 10 & 12 & 14 & 16 \\
000 & 000 & 000 & 000 \\
\hline 0.1 & 30 & 28.439 & 26.957 & 25.595 & 24.342 & 23.191 & 22.132 & 21.169 & 20.264 \\
\hline 0.2 & 30 & 18.499 & 13.628 & 11.566 & 10.692 & 10.322 & 10.165 & 10.099 & 10.071 \\
\hline
\end{tabular}

Taking into account calculated values indicated in the table, a graph of change in temperature distribution along a pipeline is built (Fig.)

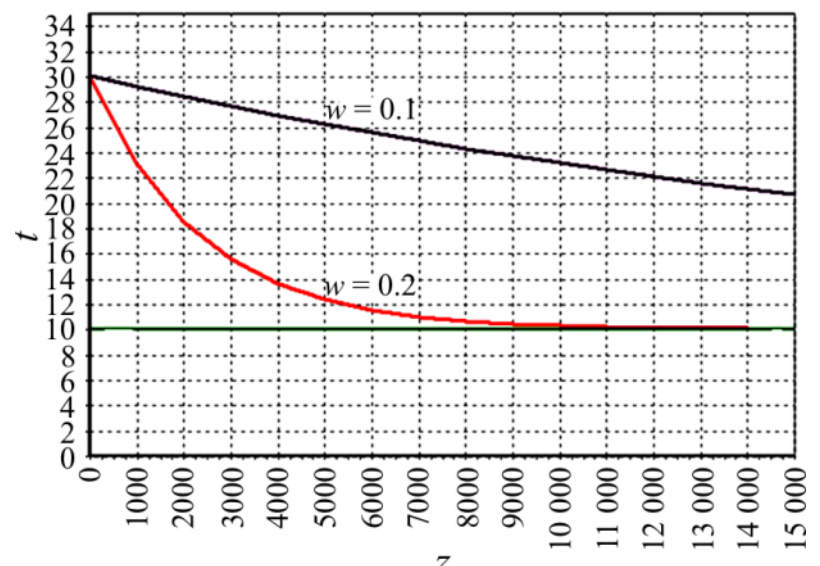

Fig. Change in distribution of temperature along the length of a pipeline

The figure shows that the bigger the length the exponentially smaller the temperature of oil emulsion flow. Herewith, temperature of oil emulsion flow at $\mathrm{z}=\infty$ is equal to temperature of the surrounding oil pipeline environment.

\section{Conclusion}

System analysis of modern state of the challenge to determine distribution of temperature of oil flow, oil emulsion and three-phase system oil-water-gas along the length of oil pipeline is performed. 
It is shown that existing works on mathematical modelling of change of flow temperature along the length of a pipeline do not consider influence of viscosity of an oil emulsion on distribution of temperature.

Therefore, the authors of the paper propose a hyperbolic law of change of oil viscosity from temperature and parabolic law of change of oil emulsion viscosity depending on concentration of emulsified water droplets in oil.
The mathematical model of distribution of oil flow temperature along the length of an oil pipeline depending on viscosity of an oil emulsion has been developed. That uses empirical law of Fourier on thermal conductivity, Newton's heat transfer law and viscous friction of oil emulsion flow. Calculated results of temperature distribution along a pipeline are presented.

\section{References}

1. Lutoshkin G.S. Sbor i podgotovka nefti, gaza i vody $\mathrm{k}$ transportu [Collection and preparation of oil, gas and water for transport]. Moscow, Nedra, 1972, $324 \mathrm{p}$.

2. Kelbaliev G.I., Rasulov S.R., Rzaev A.G. Neftianaia gidrodinamika [Petroleum hydrodynamics]. Moscow, Maska, 2015, $360 \mathrm{p}$.

3. Kelbaliev G.I., Rasulov S.R. Gidrodinamika i massoperenos $\mathrm{v}$ dispersnykh sredakh [Hydrodynamics and mass transfer in disperse media]. Saint Petersburg, Khimizdat, 2014, 568 p.

4. Leibenzon L.S. Neftepromyslovaia mekhanika. Sobranie trudov [Oilfield mechanics. Collection of works]. Moscow, Izdatel'stvo Akademii nauk SSSR, 1955, vol. III, pp.29-30, 252-273.

5. Gong J., Zhan Y. et al. Wax deposition in the oil gas two-phase flow for a horizontal pipe. Energy Fuels, 2011, 25, 4, pp.1624-1632. DOI: 10.1021/ef101682u

6. Moshfeghian M., Johannes A.H., Maddox R.N. Thermodynamic properties are important in predicting pipeline operations accurately, Oil Gas J, 2002, 100, 11, pp.56-62.

7. Zhang H., Tan Y.Q., Yang D.M. et al. Numerical investigation of the location of maximum erosive wear damage in elbows effect of slurry velocity, bend orientation and angle of elbow. Powded Technology, 2012, vol.217, pp. 467-476. DOI: 10.1016/j.powtec.2011.11.003

8. Tan Y.Q., Zhang H. et al. Numerical simulation of concrete pumping process and investigation of wear mechanism of the piping wall. Tribology International, 2012, vol. 4, pp. 137-144. DOI: 10.1016/j.triboint.2011.06.005

9. Illes B., Bobok E., Zsuga J., Toth A. Pressure and temperature drop in gas transporting pipelines. Advanced Logistic Systems, 2012, vol.6, no.1, pp.159-166.

10. Duan J.M., Wang W. et al. Energy equation derivation of the oil-gas-flow in Pipelines. Oil and Gas Science and Technology-Rev. IEP Energies nouvelles, 2013, vol. 68, no.2, pp.341-353. DOI: 10.2516/ogst/2012020

11. Enbin Liu, Liuting Yang et al. Simulation on the temperature drop rule of hot oil pipeline. The Open Fuels and Energy Science Journal, 2013, 6, pp.55-60. DOI: $10.2174 / 1876973$ X01306010055.

12. Hongjun Zhu, Guang Feng, Qijun Wang. Numerical investigation of temperature distribution in an eroded bend pipe and prediction of erosion reduced thickness. Hundawi Publishing Corparation. The Scientific World Journal, 2014, Article ID 435679, 10 p. DOI: $10.1155 / 2014 / 435679$

13. Bobok E. Fluid mechanics for petroleum engineers. Amsterdam, Elsever, 1993, 236 p.

14. Rzayev A., Guluyev G. et al. Determining oil well debit using outlet temperature information processing. Proceeding of the sixth International Conference on Management Science and Engineering Management. London, Springer-Verlog, 2013, vol.1, chap. 4, pp.55-64. DOI: 10.1007/978-1-4471-4600-1_4

15. Rzaev Ab.G., Rasulov S.R., Abasova I.A., Ragimova S.N. Razrabotka sistemy upravleniia protsessom dinamicheskogo otstoia neftianoi emul'sii [Development of a control system for the process of dynamic sludge of oil emulsion]. Oborudovanie $i$ tekhnologii dlia neftianogo kompleksa, 2014, no.5, pp.40-43.

16. Aliev T., Rzayev A., Guluyev G. et al. Indirect method measuring oil well debit.IV International Conference "Proplems of Cybernetics and Informatic", Baku, 2012, vol. III, pp.16-18. DOI: 10.1109/ICPCI.2012.6486364

17. Kasatkin A.G. Osnovnye protsessy i apparaty khimicheskoi tekhnologii [Basic processes and apparatuses of chemical technology]. Moscow, Khimicheskaia literatura, $1960,829 \mathrm{p}$.

18. Guluev G.A., Rzaev Ab.G., Rasulov S.R. et al. Matematicheskoe modelirovanie protsessa teploperedachi $\mathrm{v}$ stvole neftianykh skvazhin [Mathematical modeling of the process of heat transfer in the trunk of oil wells]. Avtomatizatsiia, telemekhanizatsiia $i$ sviaz' $v$ neftianoi promyshlennosti, 2015, no.1, pp.44-47.

19. Kelbaliev G.I., Rasulov S.R., Rzaev Ab.G., Suleymanov G.Z., Tagiyev D.B. Rheological model for flow of nonnewtonan petroleum. Reports of National academy of sciences of Azerbaijan, 2015, no.1, pp.56-59.

20. Rasulov S.R., Rzaev A.G., Abasova I.A., Ragimova S.N. Modelirovanie reologicheskikh svoistv nen'iutonovskoi nefti [Modeling the rheological properties of nonNewtonian oil]. Nen'iutonovskie sistemy $v$ neftegazovoi otrasli. Materialy mezhdunarodnoi nauchnoi konferentsii Baku, 2013, pp.210-212. 


\section{Библиографический список}

1. Лутошкин Г.С. Сбор и подготовка нефти, газа и воды к транспорту. - М.: Недра, 1972. - 324 с.

2. Келбалиев Г.И., Расулов С.Р., Рзаев А.Г. Нефтяная гидродинамика: моногр. - М.: Маска, 2015. - 360 с.

3. Келбалиев Г.И., Расулов С.Р. Гидродинамика и массоперенос в дисперсных средах: моногр. - СПб.: Химиздат, 2014. - 568 с.

4. Лейбензон Л.С. Нефтепромысловая механика: собр. тр. - М.: Изд-во Акад. наук СССР, 1955. Том III. - C. 29-30, 252-273.

5. Wax deposition in the oil gas two-phase flow for a horizontal pipe / J. Gong, Y. Zhan [et al.] // Energy Fuels. 2011. - 25, 4. - P. 1624-1632. DOI: 10.1021/ef101682u

6. Moshfeghian M., Johannes A.H., Maddox R.N. Thermodynamic properties are important in predicting pipeline operations accurately // Oil Gas J. - 2002. - 100, 11. - P. 56-62

7. Numerical investigation of the location of maximum erosive wear damage in elbows effect of slurry velocity, bend orientation and angle of elbow / H. Zhang, Y.Q. Tan, D.M. Yang [et al.] // Powded Technology. - 2012. Vol. 217. - P. 467-476. DOI: 10.1016/j.powtec.2011.11.003

8. Numerical simulation of concrete pumping process and investigation of wear mechanism of the piping wall / Y.Q. Tan, H. Zhang [et al.] // Tribology International. - 2012. - Vol. 4. P. 137-144. DOI: 10.1016/j.triboint.2011.06.005

9. Pressure and temperature drop in gas transporting pipelines / B. Illes, E. Bobok, J. Zsuga, A. Toth // Advanced Logistic Systems. - 2012. - Vol. 6, № 1. - P. 159-166.

10. Energy equation derivation of the oil-gas-flow in Pipelines / J.M. Duan, W. Wang [et al.] // Oil and Gas Science and Technology - Rev. IEP Energies nouvelles. - 2013. Vol. 68, № 2. - P. 341-353. DOI: 10.2516/ogst/2012020

11. Simulation on the temperature drop rule of hot oil Pipeline / Enbin Liu, Liuting Yang [et al.] // The Open Fuels and Energy Science Journal. - 2013. - 6. - P. 55-60. DOI: $10.2174 / 1876973 \times 01306010055$

12. Hongjun Zhu, Guang Feng, Qijun Wang. Numerical investigation of temperature distribution in an eroded bend pipe and prediction of erosion reduced thickness // The Scientific World Journal / Hundawi Publishing Corparation. - 2014. - Article ID 435679. P. 10. DOI: DOI: 10.1155/2014/435679

13. Bobok E. Fluid mechanics for petroleum engineers. - Amsterdam: Elsevier, 1993. - 236 p.

14. Determining oil well debit using outlet temperature information processing / A. Rzayev, G. Guluyev [et al.] // Proceeding of the sixth International Conference on Management Science and Engineering Management. - London: Springer-Verlog, 2013. - Vol. 1, Chap. 4. - P. 55-64. DOI: 10.1007/978-1-4471-4600-1 4

15. Разработка системы управления процессом динамического отстоя нефтяной эмульсии / Аб.Г. Рзаев, С.Р. Расулов, И.А. Абасова, С.Н. Рагимова // Оборудование и технологии для нефтяного комплекса. 2014. - № 5. - C. 40-43.

16. Indirect method measuring oil well debit / T. Aliev, A. Rzayev, G. Guluyev [et al.] // IV International Conference "Proplems of Cybernetics and Informatic". - Baku, 2012. Vol. III. - P. 16-18. DOI: 10.1109/ICPCI.2012.6486364

17. Касаткин А.Г. Основные процессы и аппараты химической технологии. - М.: Химическая литература, 1960. - 829 c.

18. Математическое моделирование процесса теплопередачи в стволе нефтяных скважин / Г.А. Гулуев, Аб.Г. Рзаев, С.Р. Расулов [и др.] // Автоматизация, телемеханизация и связь в нефтяной промышленности. - 2015. - № 1. - С. 44-47.

19. Rheological model for flow of nonnewtonan petroleum / G.I. Kelbaliev, S.R. Rasulov, Ab.G. Rzaev, G.Z. Suleymanov, D.B. Tagiyev // Reports of National academy of sciences of Azerbaijan. - 2015. - № 1. - P. 56-59.

20. Моделирование реологических свойств неньютоновской нефти / С.Р. Расулов, А.Г. Рзаев, И.А. Абасова, С.Н. Рагимова // Неньютоновские системы в нефтегазовой отрасли: материалы международной научной конференции, посвященной 85-летнему юбилею А.Х. Мирзаджанзаде. - Баку, 2013. - С. 210-212.

Please cite this article in English as:

Rzaev A.G., Rasulov S.R., Pashaev F.G., Salii M.A. Features of distribution of temperature along the length of oil pipeline. Perm Journal of Petroleum and Mining Engineering, 2017, vol.16, no.2, pp.158-163. DOI: 10.15593/2224-9923/2017.2.6

Просьба ссылаться на эту статью в русскоязычных источниках следующим образом:

Характерные особенности распределения температуры по длине нефтепровода / А.Г. Рзаев, С.Р. Расулов, Ф.Г. Пашаев, М.А. Салий // Вестник Пермского национального исследовательского политехнического университета. Геология. Нефтегазовое и горное дело. - 2017. - Т.16, №2. - С.158-163. DOI: 10.15593/2224-9923/2017.2.6 